\title{
New species of Temnocephala Blanchard (Platyhelminthes, Temnocephalida) ectosymbiont on giant water bugs, Belostoma spp. (Hemiptera, Belostomatidae) from southern Brazil ${ }^{1}$
}

\author{
José F. R. Amato ${ }^{2} \&$ Suzana B. Amato ${ }^{2}$ \\ ${ }^{1}$ Contribution number 443 of the Departmento de Zoologia, Universidade Federal do Rio Grande do Sul. \\ 2 Departamento de Zoologia, Instituto de Biociências, Universidade Federal do Rio Grande do Sul. Porto Alegre, Caixa Postal \\ 15014, 91501-970 Porto Alegre, Rio Grande do Sul, Brasil.E-mail: jfamato@terra.com.br, sbamato@ufrgs.br
}

\begin{abstract}
A new species of Temnocephala Blanchard, 1849 is described from southern Brazil, ectosymbiont on giant water bugs (aquatic hemipterans), Belostoma spp. from the greater Porto Alegre, State of Rio Grande do Sul. Some hemipterans examined were positive for this species of Temnocephala and carried bunches of eggs between the first two pairs of legs and between the first pair of legs and the rostrum, as well as adult and young specimens. The adults were darkly pigmented (greenish-brown), mimetizing the color of the hemipteran hosts. The new species is similar to Temnocephala decarloi Moretto, 1978, from Argentina, the only other species of Temnocephala from belostomatid hemipterans known to date, by having an extra long and curved cirrus, but differs by having the distal portion of the introvert not bent as a 'full-bent' smoking pipe-like, as the author depicted originally for $T$. decarloi.
\end{abstract}

KEY WORDS. Ectocommensals, Neotropical, Rio Grande do Sul, South America, taxonomy.

RESUMO. Nova espécie do gênero Temnocephala Blanchard (Platyhelminthes, Temnocephalida) ectosimbionte sobre baratas d'água, Belostoma spp. (Hemiptera, Belostomatidae) da região sul do Brasil. Uma nova espécie de Temnocephala Blanchard, 1849 é descrita para o sul do Brasil, ectosimbionte sobre baratas-d'água (hemípteros aquáticos), Belostoma spp. da região metropolitana de Porto Alegre, Estado do Rio Grande do Sul.Vários hemípteros examinados estavam positivos para esta espécie do gênero Temnocephala, inclusive com posturas sempre localizadas na face ventral entre os dois primeiros pares de apêndices locomotores, e entre o primeiro par de pernas e o rostro. Espécimes adultos e jovens de tamanhos variados também foram sempre encontrados na face ventral do hemíptero. Os vermes adultos eram pigmentados (marrom-esverdeado), mimetizando a cor do exoesqueleto de seus hospedeiros. A nova espécie é semelhante à Temnocephala decarloi Moretto, 1978, descrita da Argentina, única espécie conhecida do gênero já encontrada sobre hemípteros belostomatídeos, por ter um cirro extremamente longo e curvo, mas difere desta por ter a porção distal do 'introvert' sem a forma típica de um cachimbo ('fullbent') como ilustrada pelo autor na descrição original.

PALAVRAS CHAVE. América do Sul, ectocomensais, Neotropical, Rio Grande do Sul, taxonomia.

The story of temnocephalans of aquatic hemipterans is short but complicated. The only species so far described from hemipterans is Temnocephala decarloi Moretto, 1978, from Belostoma cummingsi De Carlo, from the Delta del Paraná, locality of Otamendi, Province of Buenos Aires, Argentina. After the examination of a single host specimen, the author considered the occurrence of temnocephalans on hemipterans as "sporadic and transitory". It has been inadequately described and figured by Moretto (1978). Damborenea \& Cannon (2001), in their review of the Neotropical species of Temnocephala, also collected specimens of this species from the type locality, but did not identify the single specimen of Belostoma found.
Vianna \& de Melo (2002) recorded as T. decarloi temnocephalans collected from one specimen of Belostoma testaceopallidum Latreille, 1807, State of Minas Gerais, southeastern Brazil, during an extensive study of aquatic heteropterans, as the first record of temnocephalans living on hemipteran hosts for Brazil. These authors also recorded for the first time another species of Temnocephala that they have called T. lanei Pereira \& Cuocolo, 1941 (a species originally found on a brachyuran freshwater crab Trichodactylus sp. of Juquiá, State of São Paulo) on several species of Limnocoris Stål, 1860 (Naucoridae Leach, 1815) and on a species of Ranatra Fabricius, 1790 (Nepidae Latreille, 1802), but also did not study them.

Revista Brasileira de Zoologia 22 (1): 107-118, março 2005 
The present report describes a new species of Temnocephala from three species of Belostoma, as well as documents photographically and through illustrations, for the first time the: 1) areas of egg deposition on the host, shape and color of the eggs; 2) morphology of the young, and live body pigmentation; 3 ) cirrus structure as revealed by de Faure's mounting medium preparations, Nomarski's differential interference contrast and phase contrast microscopy; and 4) paired dorso-lateral, posttentacular 'excretory' syncytial plates as revealed by silver nitrate staining and scanning electron microscopy.

\section{MATERIAL AND METHODS}

Live temnocephalans were obtained from belostomatid hemipterans collected from a canal located $5 \mathrm{~km}$ West of Interstate Road BR-290, locality of Arrozeira, Municipality of Eldorado do Sul $\left(30^{\circ} 01^{\prime} 36^{\prime \prime}\right.$ S, $\left.051^{\circ} 22^{\prime} 42^{\prime \prime} \mathrm{W}\right)$ and from Lago Tarumã, Municipality of Viamão ( $30^{\circ} 04^{\prime} 14^{\prime \prime}$ S, $\left.051^{\circ} 01^{\prime} 20^{\prime \prime} \mathrm{W}\right)$, State of Rio Grande do Sul. Collections of hemipterans extended from 1998 to 2003. Insects were collected with dip nets or large sand sieves, and transported live to the laboratory. Some helminths from live hosts were fixed in cold A.F.A. $\left(70^{\circ} \mathrm{GL}\right.$ ethanol - 93 parts; formalin $37 \%-5$ parts, glacial acetic acid - 2 parts), under slight cover slip pressure, stained in Delafield's hematoxylin (HuMASON 1972), cleared in cedar oil and mounted in Canada balsam. Most specimens from Lago Tarumã were fixed, with hot $\left(90^{\circ} \mathrm{C}\right) 10 \%$ buffered formalin (HF), without cover slip pressure.

The description of the new species follows the Delta System format (Dallwitz \& Paine 1986). The morphology of the paired, dorso-lateral, post-tentacular 'excretory' syncytial plates was studied in live specimens fixed with hot $\left(60^{\circ} \mathrm{C}\right)$ silver nitrate (SN) (Joffe et al. 1995, RomeIs 1968). For scanning electron microscopy (SEM), specimens were flooded with HF, washed several times with distilled water, dehydrated in a graded ethanol/acetone series and critical point dried; coated with gold and examined with a Jeol (JSM-5800) scanning electron microscope. Cirrus morphology was studied after micro dissection and mounting the cirri in de Faure's (deF) mounting medium (CANnon \& Sewell 1995). Groups of eggs, hatched and unhatched, removed by scrapping the exoskeleton of the hemipterans were dehydrated, cleared in cedar oil, and mounted in Canada balsam.

For histology, specimens were killed in HF, pre-stained in hematoxylin, sectioned with $6 \mu \mathrm{m}$, along the sagittal plane, stained with hematoxylin and eosin, and mounted in Canada balsam. Photomicrographs were taken with a Zeiss Axiolab microscope equipped with phase contrast (or just the phase contrast condenser) or with a Leica DMR Hc microscope and Nomarski's differential interference contrast (DIC) prisms. The photographic images and scanned line drawings were prepared using Adobe's Photoshop ${ }^{\circledast}$. Measurements are in micrometers $(\mu \mathrm{m})$ unless otherwise indicated; ranges are followed (between parentheses) by the mean, the number of specimens measured for a given character (when different than 11) and the standard deviation values. Measurements of cirrus length were made along the outside of the shaft wall inside the introvert swelling; measurements of total cirrus length were made along its longest side and include the introvert; measurements of width of the introvert's base include the thickness of the shaft walls but exclude the introvert swelling; measurement of the width of the introvert swelling were taken at the widest point; all cirrus measurements were taken from cirri extracted from the specimens by micro dissection and mounted individually, laying flat, in deF. The prostatic bulb measurements include the muscular walls. The terminology to describe the male reproductive structures follows Cannon (1993), Cannon \& Sewell (1995), and SEwell \& Cannon (1998). Drawings were made with a drawing tube on a Leitz Dialux 20-EB microscope.

The holotype and some paratypes fixed in HF and cold A.F.A., as well as slides containing individual cirri in deF and unhatched eggs, was deposited in the Coleção Helmintológica do Instituto Oswaldo Cruz (CHIOC), Rio de Janeiro, RJ, Brazil.

\section{RESULTS}

\section{Temnocephala curvicirri sp. nov. Figs 4-35}

Description (based on: 167 specimens collected; 11 adult whole-mounted specimens; 49 juveniles; four specimens mounted on stubs for SEM; 11 cirri mounted in deF; nine mounted specimens, fixed in $\mathrm{SN}$, two specimens embedded in paraffin for sectioning); 11 specimens killed in cold A.F.A. under slight cover slip pressure, measured:

External characteristics. Body length (without tentacles) 1.73-3.14 mm (2.16 mm, 459); 1.02-2.26 mm (1.43 mm, 355); adhesive disk sub-ventral, pedunculate, 329-696 (492, $\mathrm{n}=9$, 108 ) in diameter, much narrower than total body width; live body pigmentation present (Fig. 5), greenish-brown, well pronounced in adult specimens. Recently hatched and juvenile specimens still not pigmented. Eyespots round, with red pigment in live specimens (Fig. 7); pigment dissolving if specimens are fixed in ethanol, but not in formalin.

Epidermal mosaic (demonstrated through staining with SN) with two dorso-lateral, post tentacular (Figs 9, 15-17 - head arrows), 'excretory' syncytial plates, extending from the base of first and fifth tentacles, respectively; left plate 422-566 (492, n $=4,76)$ long, right plate 444-555 $(519, \mathrm{n}=4,52)$ long; length of 'excretory' syncytial plates/total body length, without tentacles, relationship 3.33:1. Excretory pore (nephridiopore) inside the area of each 'excretory' syncytial plate, at the widest point, displaced toward the inner side of the plate (Figs 9, 15-17).

Alimentary system. Mouth surrounded by a small muscular sphincter (Fig. 7), between first and second thirds of body; pharynx wider than long (Figs 10 and 11), 137-322 (203, n = 7, 64) long, 282-661 $(445, \mathrm{n}=7,133)$ wide, with a large sphincter; esophageal glands surrounding it at base (Fig. 33 eg); in- 

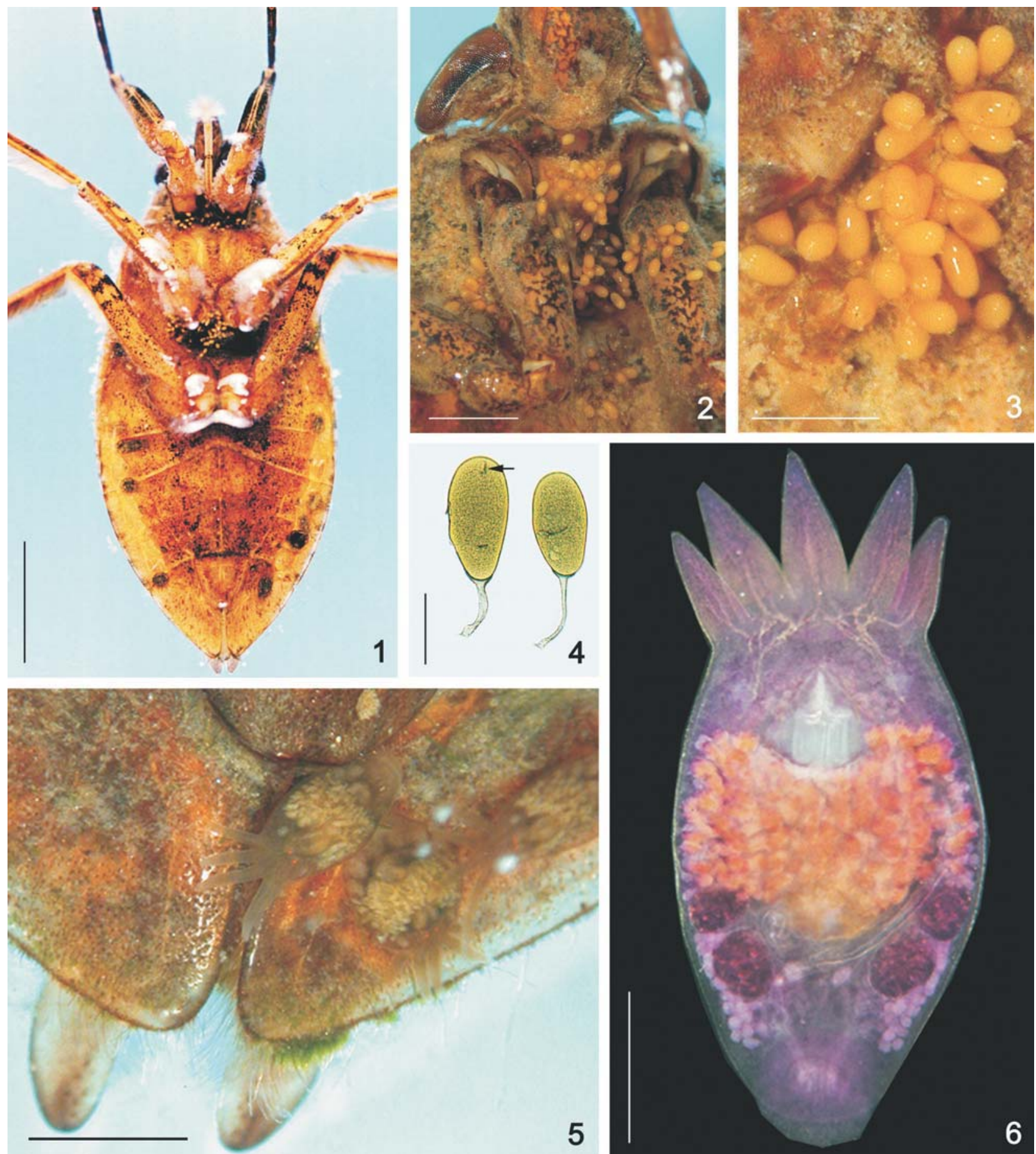

4
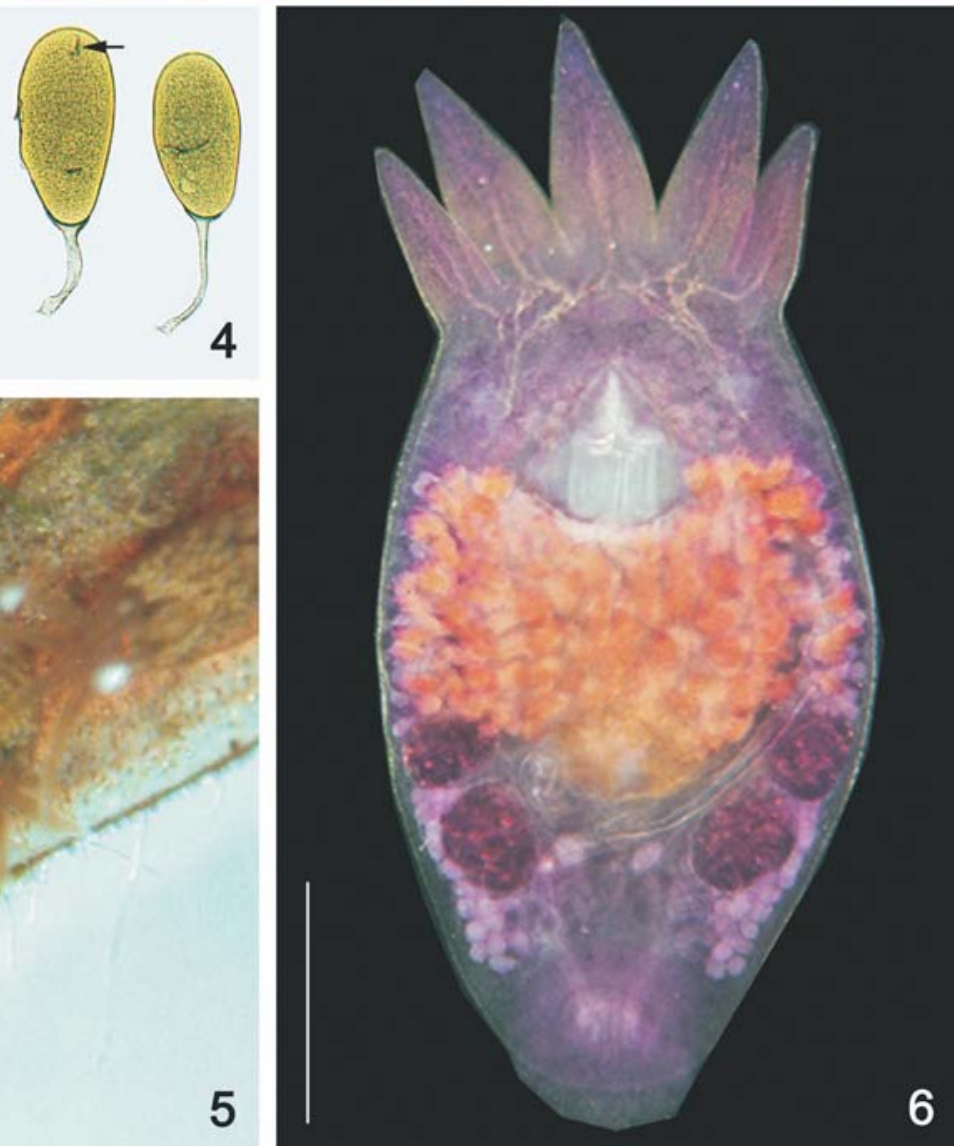

Figures 1-6. (1-3 and 5) Belostomatid hemipteran hosts of Temnocephala curvicirri sp. nov.: (1) Belostoma dentatum, ventral view, showing darkly pigmented temnocephalans on the ventral surface of the abdomen and areas of egg deposition, bar = 10 mm; (2-3) Belostoma dilatatum, ventral view, showing the egg bunches of temnocephalans, bars $=2 \mathrm{~mm}$; (4) unhatched eggs, showing the smooth anti-peduncular pole and the sub-terminal filament (arrow), bar $=250 \mu \mathrm{m} ;$ (5) B. dilatatum, live adult specimen showing the greenish-brown body pigment and red pigment of eyespots, bar $=2 \mathrm{~mm}$; (6) adult specimen of $T$. curvicirri sp. nov. killed in hot formalin, without compression, seen under partial phase contrast illumination, bar $=500 \mu \mathrm{m}$. 

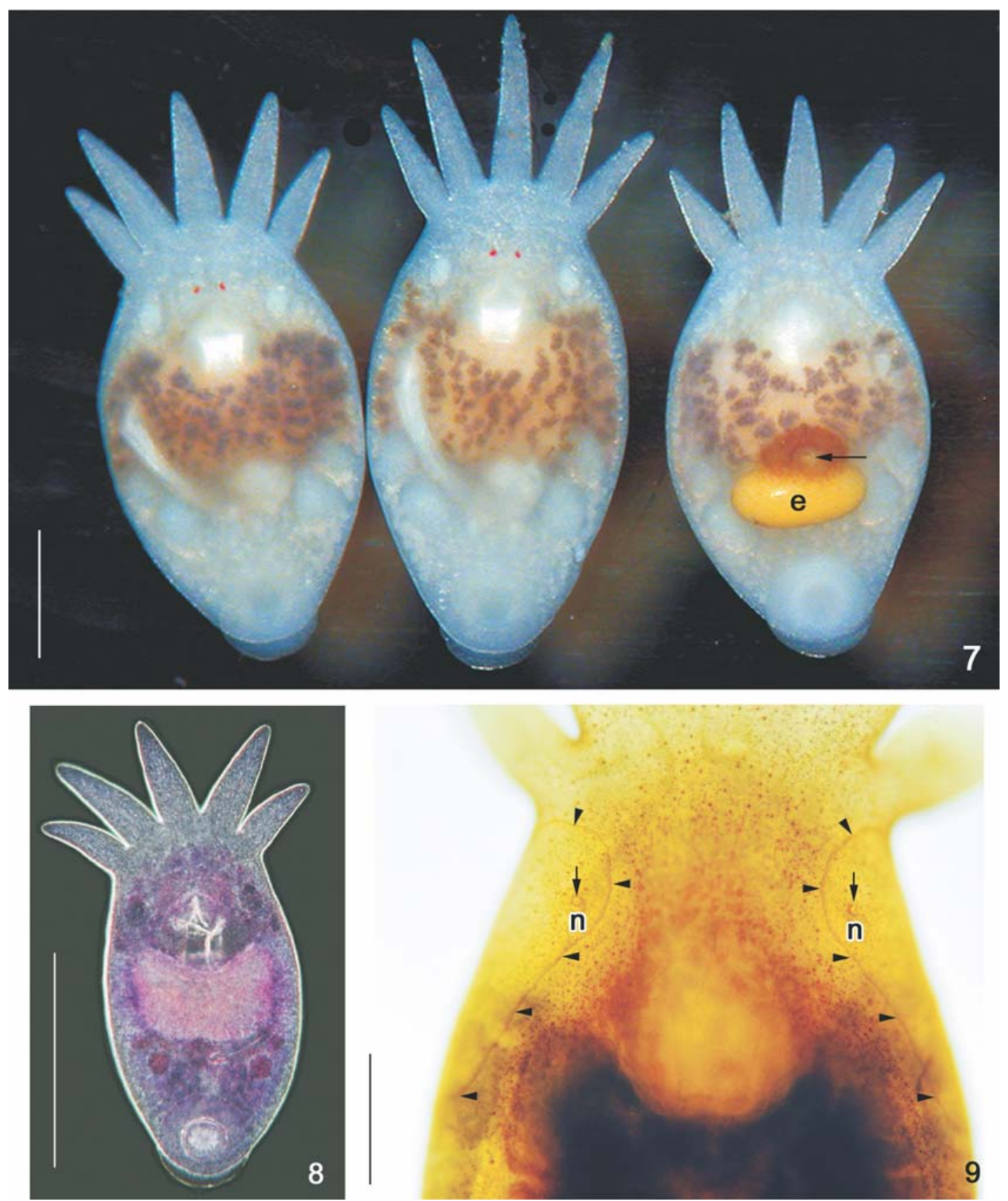

Figures 7-9. Temnocephala curvicirri sp. nov.: (7) adult specimens killed in HF, dorsal view (left and center specimens), ventral view (right specimen) showing an egg (e) ready to be laid and a light brown, granular material around the genital pore (arrow); the individual pattern of vitellaria and the preserved, red eyespot pigment, bar $=500 \mu \mathrm{m}$; (8) young specimen still without vitellaria, seen under partial phase contrast illumination, bar $=500 \mu \mathrm{m}$; (9) syncytial 'excretory' plates seen in specimen stained with silver nitrate with offcenter nephridiopores ( $\mathrm{n}$, arrows), bar $=250 \mu \mathrm{m}$.

testine saccular, with conspicuous septations in young and in adults; intestinal walls thick (Fig. 33 is).

Excretory system. Excretory ampullae, round, at level of mouth (Figs 10-11), generally directed outwards while the nephridiopore is off-center in the anterior, wider portion of the 'excretory' syncytial plates.

Revista Brasileira de Zoologia 22 (1): 107-118, março 2005 

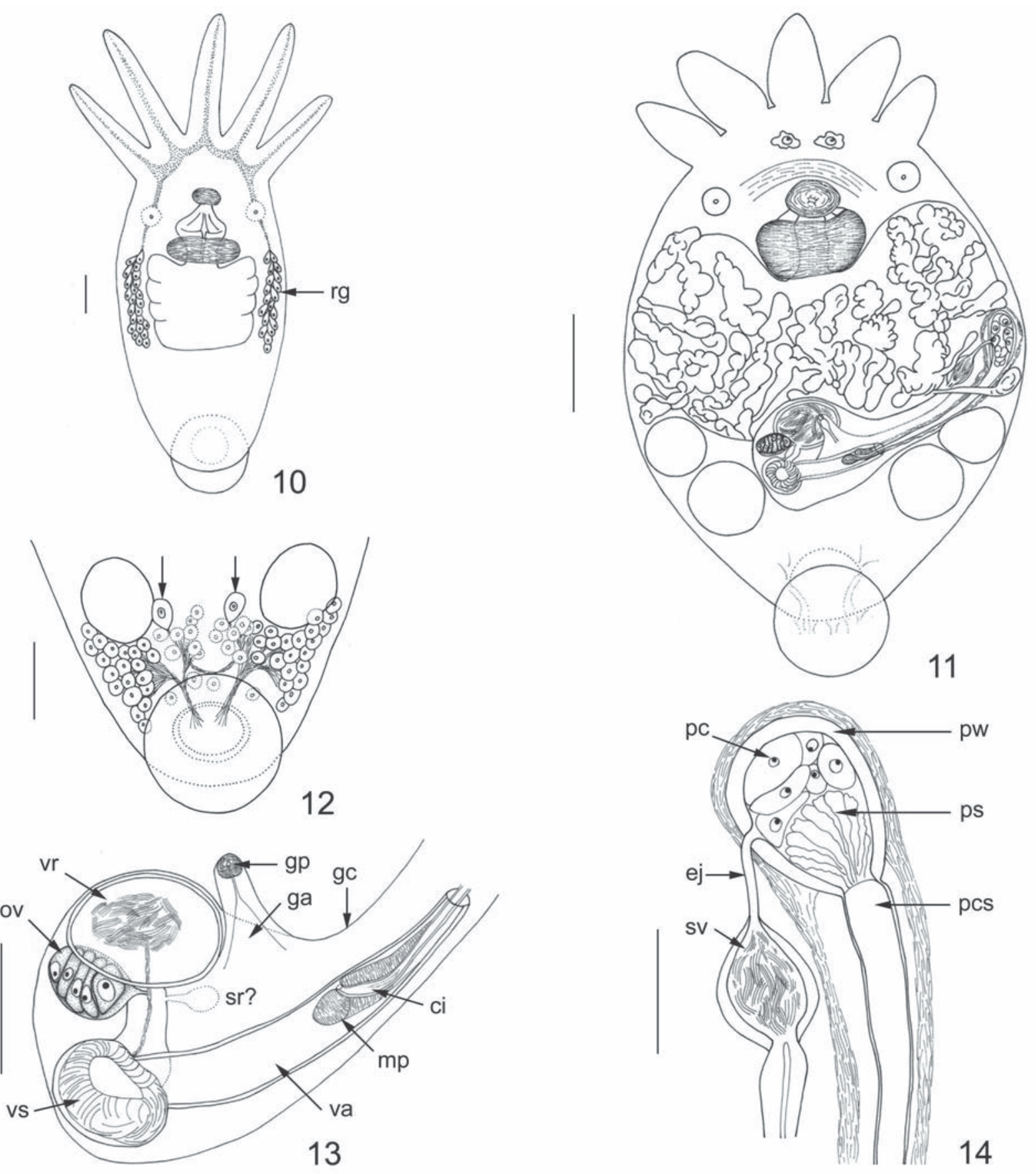

Figures 10-14. Temnocephala curvicirri sp. nov.: (10) very young specimen showing the rhabdite producing glands (rg), extending along the sides of intestinal sac, still uncovered by vitellaria, and its ducts entering tentacles, bar $=100 \mu \mathrm{m}$; (11) incomplete diagram of an adult specimen (holotype) killed with cold A.F.A and slight cover slip pressure, bar $=500 \mu \mathrm{m}$; (12) adhesive disc glands, including the pair of larger glands between testes (arrows), bar $=200 \mu \mathrm{m}$; (13) female reproductive complex, inside genital capsule (gc), showing vesicula resorbens (vr), ovary (ov), vagina (va), cirrus (ci) entering the vagina, 'muscular plug' (mp) of the cirrus sheath and genital atrium (ga) leading to the genital pore (gp), bar $=200 \mu \mathrm{m}$; (14) prostatic bulb receiving, laterally, the ejaculatory duct: prostatic cells $(p c)$, prostatic secretion (ps), prostatic bulb muscular wall (pw), seminal vesicle (sv), ejaculatory duct (ej), proximal portion of cirrus shaft (pcs), bar $=100 \mu \mathrm{m}$. 

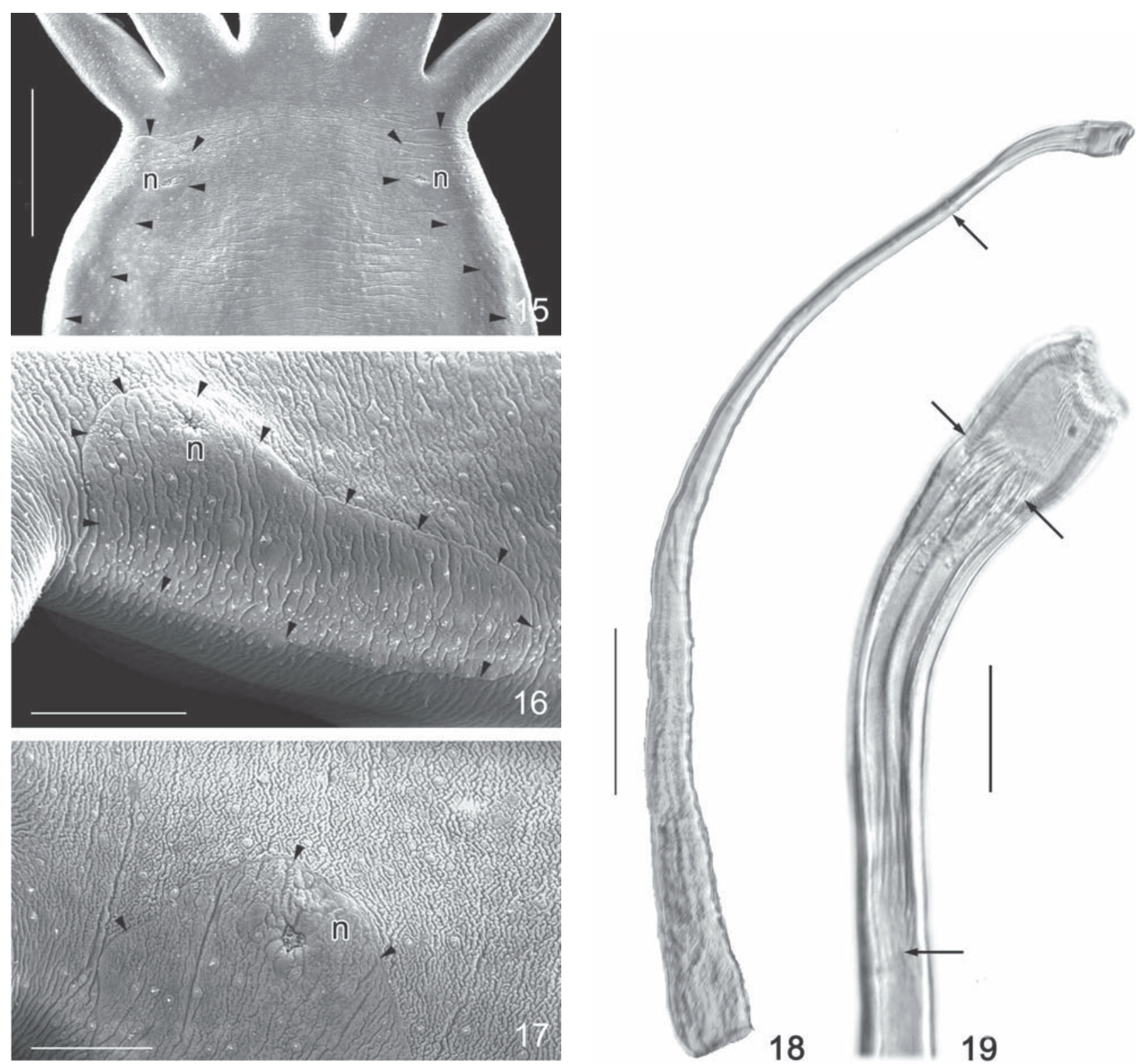

Figures 15-17. Temnocephala curvicirri sp. nov. (SEM): (15) anterior region of body showing the dorso-lateral, 'excretory' syncytial plates (head arrows), and nephridiopores $(n)$, bar $=200 \mu \mathrm{m}$; (16) left, dorso-lateral 'excretory' syncytial plate, bar = 100 $\mu \mathrm{m}$; (17) higher magnification of the left syncytial plate, showing the off-center nephridiopore $(n)$, and the clear limits of the plate (head arrows), bar $=50 \mu \mathrm{m}$; (18-19) photomicrographs of the cirrus, seen with Nomarski's DIC microscopy: (18) entire cirrus and proximal limit of the introvert (arrow), bar $=150 \mu \mathrm{m}$; (19) introvert (single arrow indicates the proximal limit of the introvert; double arrows indicate the proximal limit of the introvert's swelling), bar $=30 \mu \mathrm{m}$.

Glands. Rhabdite producing glands large, numerous, forming bunches of 19-26 (24) glands, in lateral fields; extending along the length of the intestinal sac, best observed in very young specimens (Figs 8 and 10); rhabdite tracts clearly visible, uniting just before entering tentacles (Fig. 10).
Cyanophilous glands inconspicuous, probably separated from each other, not forming two, lateral, 'grape-like' bunches. Two Haswell's cells irregular shaped, showing little affinity with hematoxylin, in front of the eyespots and the brain transverse band (Figs 11 and 29 hc, arrows); left cell in pair 82-128 (104, 


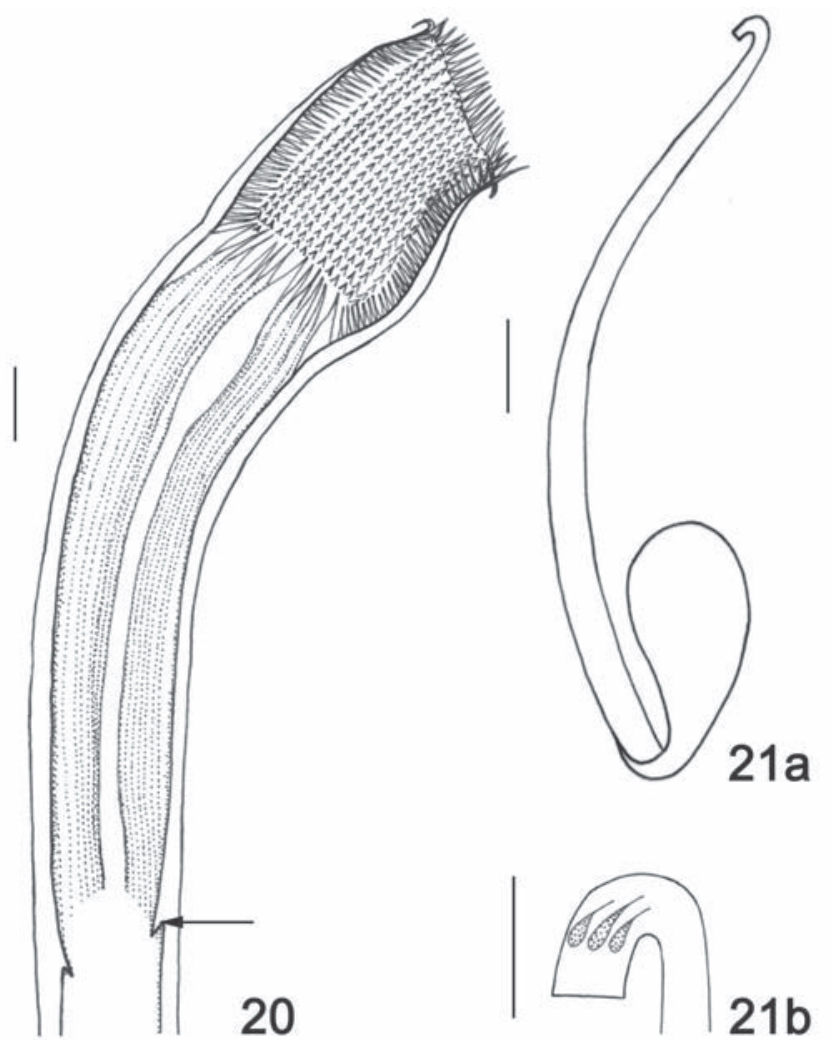

Figures 20-21. (20) Temnocephala curvicirri sp. nov.: line drawing of the cirrus' introvert, (arrows indicate proximal limit of introvert), bar $=30 \mu \mathrm{m} ;(21)$ cirrus and prostatic bulb of $T$. decarloi, redrawn from MoRetTo's original description: (21a) cirrus and prostatic bulb, bar $=100 \mu \mathrm{m}$; (21b) the 'full-bent' smoking pipe-like distal portion of the introvert, bar $=50 \mu \mathrm{m}$.

$\mathrm{n}=9,16)$ across, right cell 55-125 (90, $\mathrm{n}=9,19)$ across. Esophageal glands inconspicuous; staining reddish-purple; forming a collar between pharynx and intestinal sac (Fig. 33 eg). Ootype glands conspicuous. Disc glands between adhesive disc and genital complex, forming two, lateral bunches extending from mid-level of posterior testes to anterior border of adhesive disc uniting to two, large, more central cells (Fig. 12 arrows). Shell glands between testes of the same side, difficult to see.

Reproductive system. Female. Gonopore between middle and posterior thirds of body (Fig. 7 arrow); ovary pyriform, 103$210(140, \mathrm{n}=11,28)$ long, 80-137 (98, $\mathrm{n}=11,18)$ wide (Figs 13 and 31); seminal receptacles inconspicuous; vitellaria, extending laterally beyond the limits of intestinal sac and touching sides of body (even in unflattened specimens), superimposing the rhabdite producing glands, and having a unique shape which varies from individual to individual and from dorsal to ventral sides of the body (Figs 6, 7 and 28); genital atrium spacious, elongate (Figs 13 and 31), vagina long (Figs 13 and 32 va), with a well developed sphincter at the proximal end, opening in front of cirrus introvert; vesicula resorbens (Figs 13, 31 and $33 \mathrm{vr}$ ), with thick wall, 183-375 $(277, \mathrm{n}=6,71)$ long, 229-403 $(299, \mathrm{n}=6,65)$ wide, indenting intestinal sac and vitellaria, posteriorly. Eggs with long peduncles, deposited in groups under the rostrum, between the coxopodites of the first and the second pair of legs (Figs 1, 2 and 3), always deposited on the ventral side of body, anti-peduncular pole smooth, but with filament sub-terminal (Fig. 4 arrow), 524-638 (569, $\mathrm{n}=9,34)$ long, 273-319 $(296, \mathrm{n}=9,19)$ wide, peduncles $34-55(47, \mathrm{n}=10,8)$ long, 2.7 wide.

Male. Testes four, usually rounded, slightly oblique; right anterior testis round, $183-458(283, \mathrm{n}=10,82)$ long; 92-302 $(232, \mathrm{n}=10,57)$ wide; right posterior testis round to oval, 256549 (357, $\mathrm{n}=10,88)$ long, 211-376 (291, $\mathrm{n}=10,53)$ wide; left anterior testis round, 192-376 $(272, \mathrm{n}=10,65)$ long, 183-366 $(249, \mathrm{n}=10,56)$ wide; left posterior testis irregularly oval, 274$550(360, \mathrm{n}=10,85)$ long, $210-366(269, \mathrm{n}=10,54)$ wide; both deferent vessels unite in large, pyriform, thick-walled, seminal vesicle, 394-421 (407, $\mathrm{n}=2,20)$ long, $62-110(88, \mathrm{n}=10,17)$ wide; genital capsule present, observed in sagittal section (Fig. $33 \mathrm{gc}$ ); prostatic bulb (Figs 14 and 30) with thick, muscular walls, 211-284 (238, $\mathrm{n}=5,27)$ long, 101-128 $(112, \mathrm{n}=5,10)$ wide, enclosed as well as the cirrus, in a muscular 'sleeve-like' tissue, sometimes showing folds; proximal portion with few, large cells and prostate secretion in the distal portion; prostate bulb receives the ejaculatory duct on either side (Fig. 14); cirrus when viewed from top, apparently straight, curved in lateral view, 9531062 (1003, $\mathrm{n}=4,54)$ long, shaft 659-889 (799, $\mathrm{n}=4$; 98) long, shaft base 61-84 (72, $\mathrm{n}=4 ; 10)$ wide (Fig. 18); introvert never observed more everted than is shown in figures 22-27, 132-164 $(155, \mathrm{n}=4,20)$ long, $16-20(18, \mathrm{n}=4,2)$ wide at base; maximum introvert width at level of swelling, 25-32 (27, $\mathrm{n}=4,3)$, introvert's swelling portion $36-41(39, \mathrm{n}=4,2)$ long, observed in progressive focusing planes with the Nomarski's DIC microscopy (Figs 22-27). In transversal section, the introvert's swelling shows approximately 55 longitudinal rows of fine spines and approximately 55 spines per row; each row can be seen as teeth of a comb, with the 'handle' positioned backwards (Fig. 20). Each spine in the perimeter of the swelling portion is approximately $7 \mu \mathrm{m}$ long. Bottom of the introvert's swelling portion receives a group of larger spines which are placed circularly on the inner wall. Among these are four still wider, 'blade-like' spines placed in the cardinal positions (Figs 19, 20 and 24-26 arrows) and resting on the wall of the introvert. Proximal limit of introvert marked with a narrowing of the lumen's diameter, and is seen from the side as two fine spikes (Figs 19 and 20 arrows). Ratio between total length of cirrus and maximum width of shaft's base 12.6-15.4; ratio between total length of cirrus and total length of introvert 6.5-7.2.

Synonym. T. decarloi of Vianna \& DE Mello (2002).

Type host. Belostoma dilatatum (Dufour, 1863).

Other hosts. B. dentatum (Mayr, 1863), B. elegans (Mayr, 1871), B. testaceopallidum Latreille, 1807 (State of Minas Gerais). 

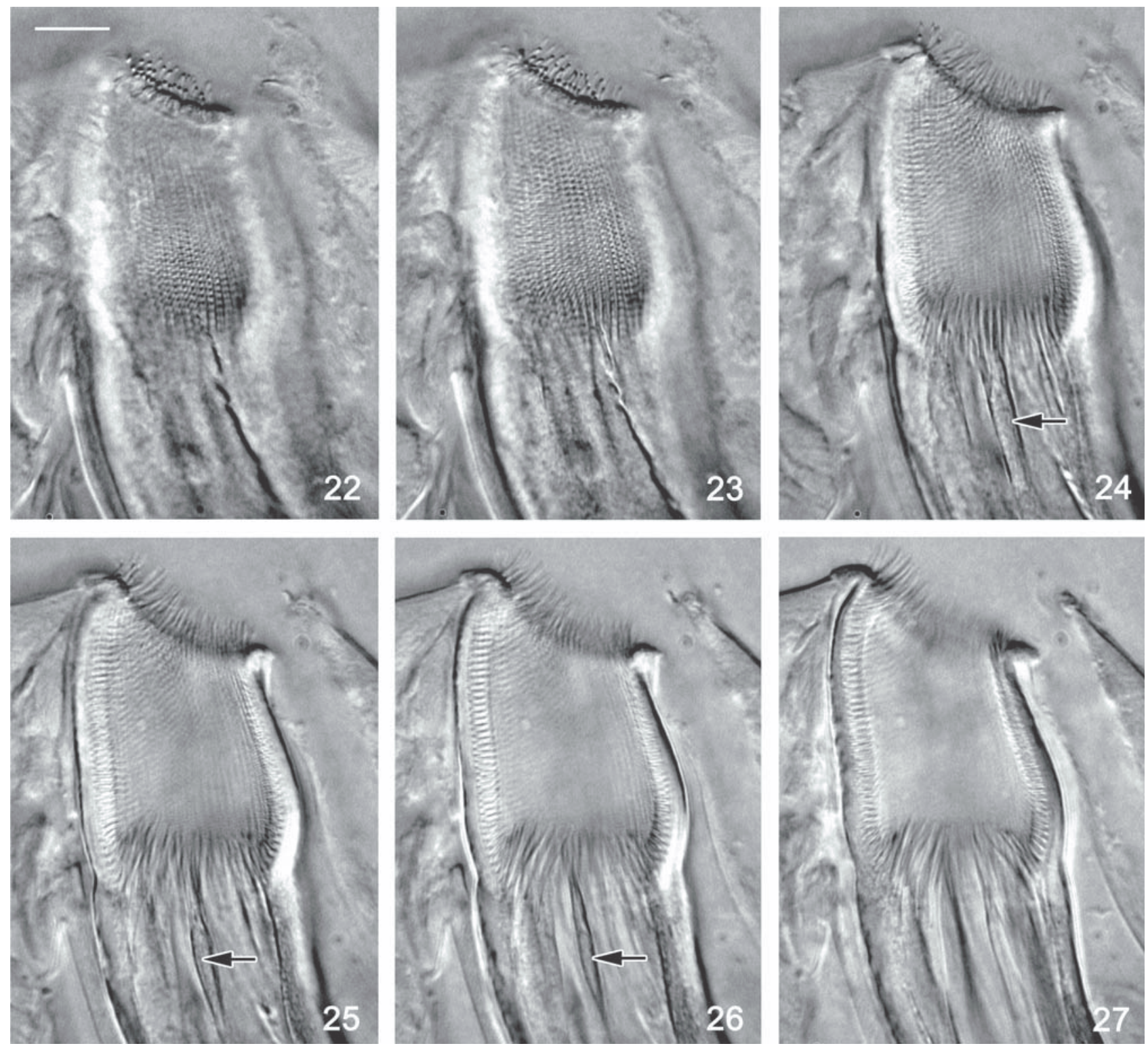

Figures 22-27. Temnocephala curvicirri sp. nov. optical frontal sections of the cirrus' introvert swelling portion, as seen in different focusing planes, from the external surface to the mid-section, with the Nomarski's DIC microscopy. Arrows in figures 24-26 indicate one of the four large, cardinal spines (arrows). Bar $=10 \mu \mathrm{m}$, valid to all figures.

Site. Ventral side of body; eggs located under the rostrum and between the coxopodites of the first and second pairs of legs.

Type locality. Lago Tarumã, Viamão, Rio Grande do Sul (30 $\left.04^{\prime} 14^{\prime \prime} \mathrm{S}, 051^{\circ} 01^{\prime} 20^{\prime \prime} \mathrm{W}\right)$.

Other localities. Stream and canal $\left(30^{\circ} 01^{\prime} 36^{\prime \prime} \mathrm{S}, 051^{\circ} 22^{\prime}\right.$ 42 "W), on the road to the town of Arrozeira, Municipality of Eldorado do Sul, Rio Grande do Sul (2 km to the North of Interstate Road BR-290), Brazil; Retiro das Pedras, Brumadinho,
Minas Gerais.

Deposited specimens. CHIOC \# 36461 - holotype fixed in AFA, CHIOC \# 36462a - paratype fixed in AFA, CHIOC \# 36462b-c - paratypes fixed in HF, \# 36462d - paratype fixed in $\mathrm{SN}, \mathrm{CHIOC}$ \# 36462e - cirrus from paratype, in deF, \# 36462f hatched eggs, \# 36462g - unhatched eggs (all from type host specimen SBA-1727); \# 36463 - cirrus from paratype, in deF, from host SBA-1630; \# 36464 - paratype fixed in AFA, from host SBA-1120; \# 36465 - paratype fixed in AFA, from host SBA-1150. 

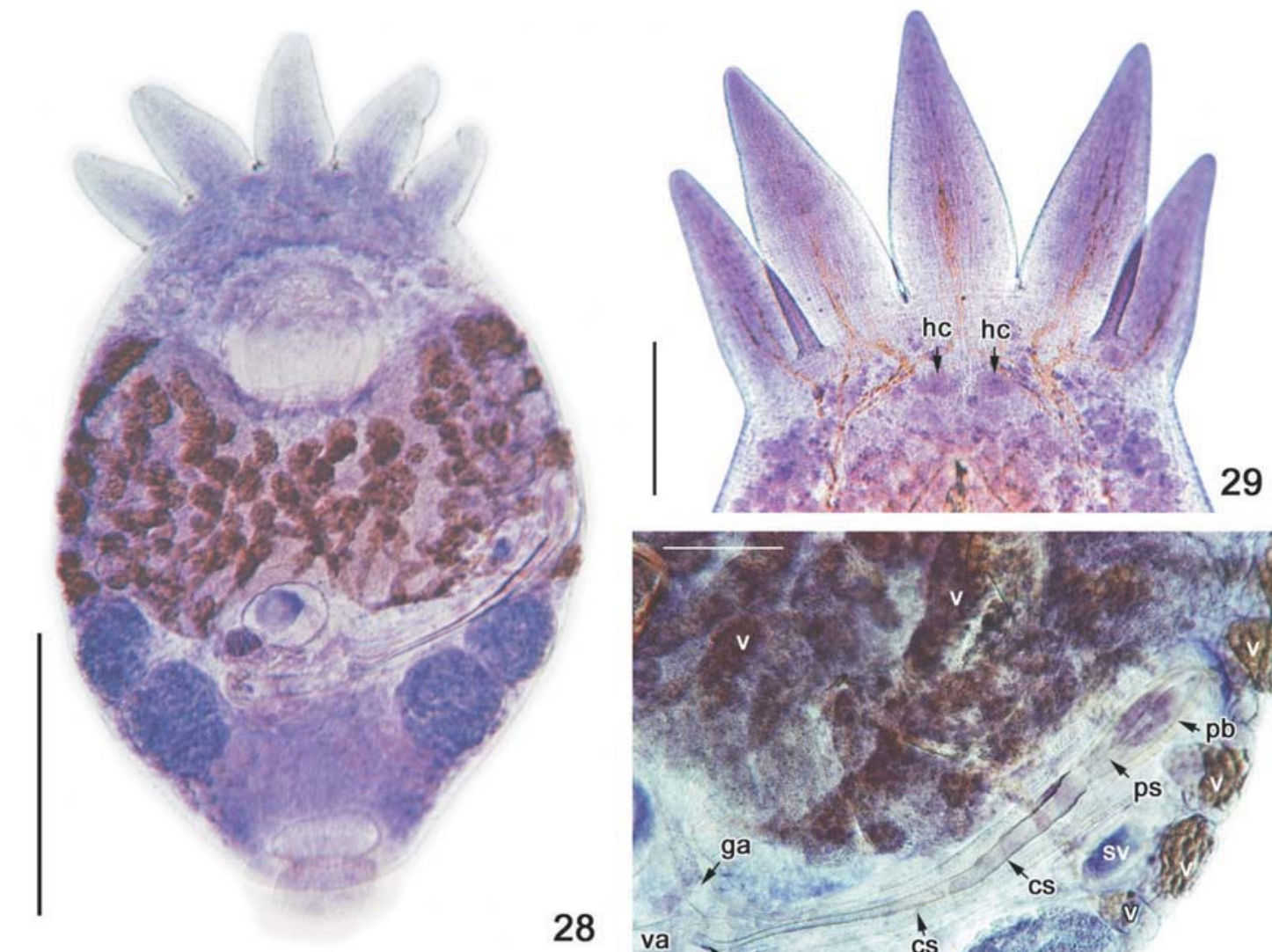

28
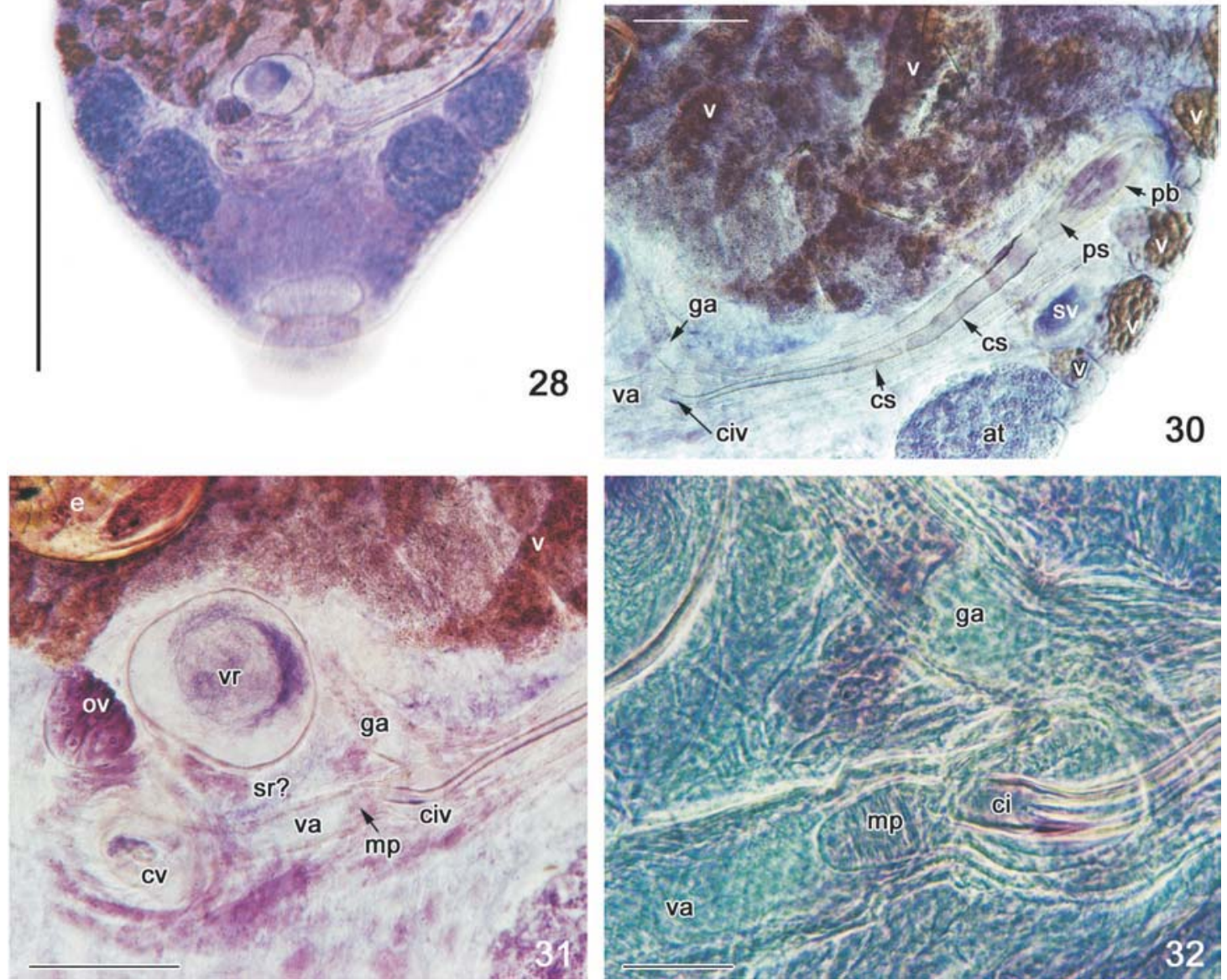

Figures 28-32. Temnocephala curvicirri sp. nov.: (28) photomicrograph of the holotype, ventral view, killed by cold A.F.A. under slight cover slip pressure, bar $=1 \mathrm{~mm}$; (29) anterior region of a specimen killed by HF, showing the rhabdite tracts and the two Haswell's cells (arrows - hc), bar = $250 \mu \mathrm{m}$; (30) entire cirrus inside the 'sleeve-like' sheath (cs) entering the vagina (va), cirrus introvert (civ), prostatic bulb ( $\mathrm{pb}$ ) showing the large prostatic cells, prostatic secretion (ps), seminal vesicle (sv), genital atrium (ga), vitellaria (v), and anterior testis (at), bar $=250 \mu \mathrm{m}$; (31) female reproductive complex and the distal portion of the cirrus entering the vagina. Vagina with large sphincter (cv) in the direction of the ootype, ovary (ov), vitellaria (v), vesicula resorbens (vr), genital atrium (ga), 'muscular plug' (mp) entering the vagina (va), cirrus introvert (civ), seminal receptacles? (sr?), and egg (e), bar = $250 \mu \mathrm{m}$; (32) higher magnification of the introvert's swelling portion (ci), 'muscular plug' (mp) entering the vagina (va), and the genital atrium (ga), bar $=50 \mu \mathrm{m}$. 


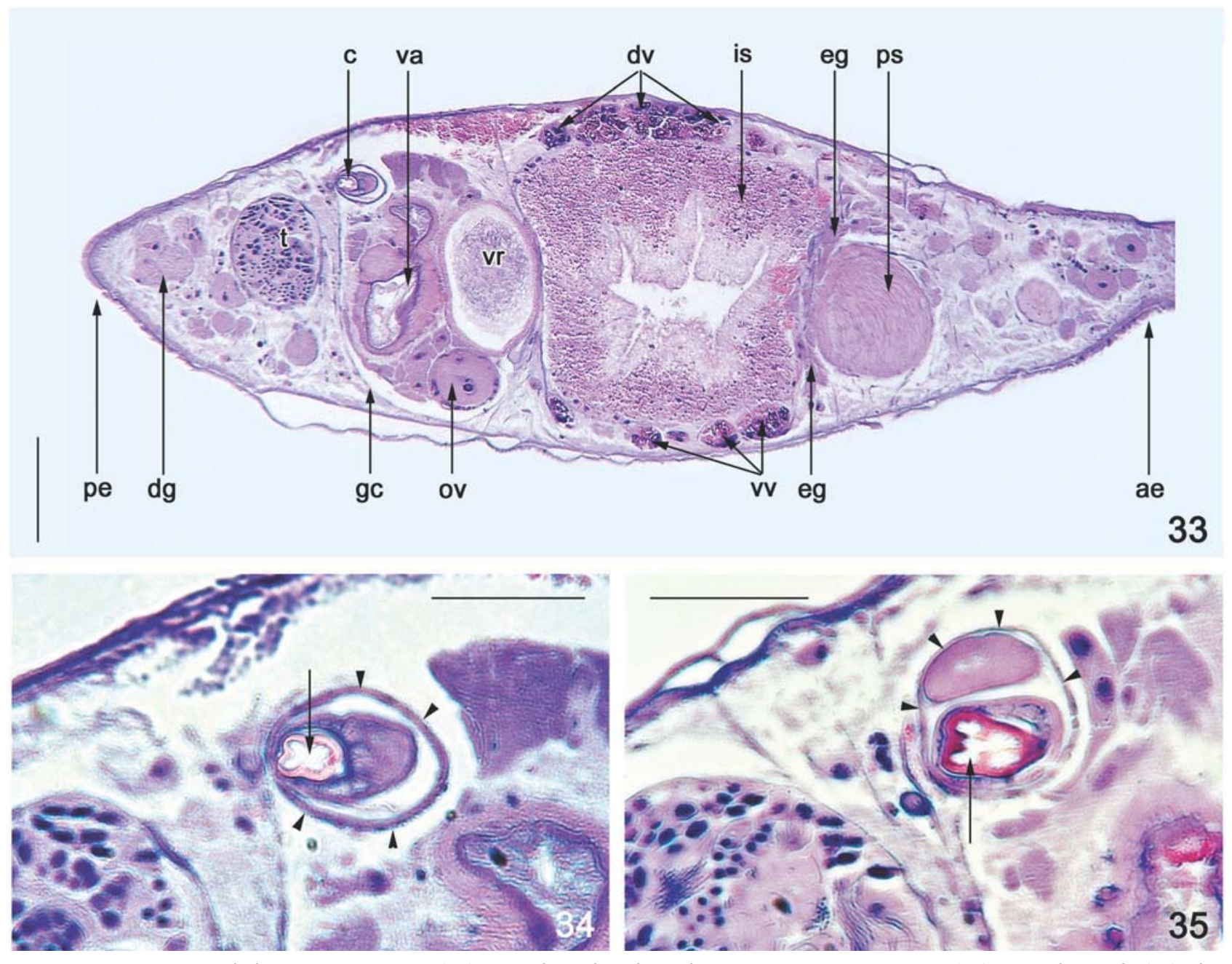

Figures 33-35. Temnocephala curvicirri sp. nov.: (33) sagittal axis histological section: posterior extremity (pe), genital capsule (gc), disc glands (dg), ovary (ov), vesicula resorbens (vr), ventral vitellaria (vv), dorsal vitellaria (dv), esophageal glands (eg), cirrus (c), vagina (va), intestinal sac (is), pharynx sphincter (ps), and anterior extremity (ae), (34) higher magnification of transversal section of the cirrus, showing the four large 'blade-like' spines in the introvert (arrow) and the muscular sheath around cirrus (head arrows), bar $=50 \mu \mathrm{m} ;(35)$ transversal section of the cirrus, showing spines in the introvert (arrow) in a more distal plane and the muscular sheath around cirrus (head arrows), bar $=50 \mu \mathrm{m}$.

Etymology. (L. curvus, m. curved + cirrus - the copulatory structure). Compound name in the genitive. Temnocephala curvicirri sp. nov. having the long cirrus in the shape of a bow. The specific epithet curvicirri was given because the tip of the cirrus' introvert is not bent (as in a full-bent smoking pipe), as is the cirrus in T. decarloi from Argentina (Figs 21a and 21b).

Remarks. Temnocephala curvicirri sp. nov. is described from southern Brazil, epizoic on several species of giant water bugs of the genus Belostoma. Many species of this genus occur together in the same localities. Within the genus Belostoma, some species are large: $B$. dentatum (30 specimens examined - two specimens positive); B. dilatatum (10 specimens examined - six specimens positive), and B. elongatum (30 specimens examined - all negative) while other species are small: B. elegans (93 specimens examined - one specimen positive) for T. curvicirri sp. nov.

Although Vianna \& DE Melo (2002) described in detail the hemipterans and the characteristics of the streams they surveyed, did not describe the only adult and the two young temnocephalan specimens found, nor presented illustrations (drawings and/or photomicrographs), which could ensure the correct species identification of both species of temnocephalans. These authors must have used their own work (NIESER \& DE MELo 1997) to identify the hemipterans. Vianna \& De Melo (2002) wrote: "the species diagnose is based on the penis morphology which 
is a long and sigmoid structure". But the cirrus (not penis) is not "sigmoid". Figure 21a-b show that the morphology of the cirrus of T. decarloi, described by MoretTo (1978) and the cirrus in the Brazilian specimens (Fig. 20) have different shapes, thus not warranting using the name $T$. decarloi for the specimens reported by VianNa \& DE MELo (2002) from the State of Minas Gerais. After seen pictures of the adult specimen from B. testaceopallidum, identified as $T$. decarloi, we saw that the cirrus was exactly like the one being now described for T. curvicirri sp. nov., i.e., it is not bent as it is shown in figure 21a-b.

The cirrus in T. curvicirri sp. nov., as well as the prostatic bulb, are enclosed in a sleeve-like tissue which is highly muscular at the distal end. This 'muscular plug' covers the cirrus' extremity as it enters the vagina. Figures 31 and 32 show it advancing in front of the spiny, swollen section of the cirrus, as if it was 'devised' to 'protect' the vagina. In some specimens with the cirrus still not penetrating the vagina this 'muscular plug' is found displaced to the side. These peculiarities might end up being common to T. decarloi.

Damborenea \& CANNon (2001) mentioned that the prostatic bulb, in the Neotropical temnocephalans, always receives the ejaculatory duct on the proximal end while in the Australian species the prostatic bulb receives the ejaculatory duct laterally. In this respect (Fig. 14) the new species and, probably $T$. decarloi, are more like the Australian species.

At present, with the impossibility of examining specimens from Argentina (being used by Dr M. C. Damborenea to redescribe T. decarloi - Pers. Comm.) and with the impossibility of examining the only adult specimen collected in the State of Minas Gerais (sent to Dr Walter Dioni, in México - Pers. Comm. by Dr A. L. De Melo), one has only to wait.

The present work with the temnocephalans of Belostoma spp. has shown us along the years that temnocephalans, in general, should always be collected from live hosts and should be killed/fixed preferentially by HF. A number of specimens pressed between slide and cover slip should be immediately separated for internal morphometry. The specimens killed with HF but not pressed (Fig. 6) will not allow the observation of various female characters. Besides, it is also necessary to kill live specimens in SN to determine the shape of the 'excretory' syncytial plates. For histology and SEM the specimens killed in $\mathrm{HF}$ are fine. Another aspect that is necessary to document is the shape of the unhatched eggs, to show if the anti-peduncular pole has any filament or if the filament is lateral or subterminal. The eggs of some species we are currently studying are symmetrical, having the filament in the anti-peduncular pole or displaced to the side while in others they are asymmetrical having the filament displaced to the side. Temnocephala curvicirri sp. nov. has symmetrical eggs, with the filament subterminal, displaced to the side (Fig. 4 arrow).

The body pigmentation displayed by some temnocephalan species is becoming critical to be observed in live specimens; our figure 5 shows that the specimens from the differ- ent species of Belostoma show the highest degree of body pigmentation among the several species of Temnocephala we have observed alive. They tend to be mimetic with the hemipterans' exoskeleton. Figure 1 shows a specimen of $B$. dentatum, which is lighter in color, where is possible to see several live, darkly pigmented temnocephalans.

The 'excretory' syncytial plates of T. curvicirri sp. nov. (Figs 9, 15-17) are similar to those drawn by Damborenea \& CANNon (2001) for T. decarloi. The tentacles observed, photographed, and filmed while our specimens were alive, are held in the same manner described by these authors, with the three central tentacles extended showing that they do share a common base. The eyespots are red in live specimens and remain visible after fixation and preservation in formalin (Fig. 7).

The rhabdite producing glands can only be observed in young specimens where the vitellaria, dorsal and ventral, are not yet developed to conceal them. Figure 10 shows the rhabdite ducts from the two groups of cells run forward on the two sides of the intestinal sac. The disc secretion glands are large forming two groups that run latero-posteriorly from the posterior testes (Fig. 12 arrows) and appear whitish under partial phase contrast illumination (Fig. 6). Joining these groups of disc gland cells there is a pair of large and also whitish cells located between the two posterior testes. These cells stain well with carmine and have been observed in other species of the genus Temnocephala.

\section{ACKNOWLEDGEMENTS}

The authors are indebted to Prof. Abner Chiquieri, Departmento de Línguas, Universidade Federal Rural do Rio de Janeiro, Seropédica, RJ, for his advice on the correct formation of the specific name of the new species; to Drs José Ricardo Inácio Ribeiro and Jorge Luiz Nessimian, Universidade Federal do Rio de Janeiro, for identifying the belostomatid hemipterans; to Drs Jorge Ernesto de Araújo Mariath, Rinaldo Pires dos Santos, Frederico Widholzer, and their research associates in the Laboratório de Anatomia Vegetal, Instituto de Biociências, UFRGS, for the help with the Leica DMR Hc DIC microscope; to Dr David Driemeier, Departamento de Patologia e Clínica Veterinária, Faculdade de Veterinária, UFRGS, for the histological sections; to Dr Maria Cristina Damborenea, Curator of Helminths, Museo de La Plata, La Plata, Republica Argentina, for personal communication on her specimens of $T$. decarloi collected from the type locality, Otamendi, Buenos Aires; to Luiz Carlos Campos Daudt for the line drawing of figure 20, morphometry, and invaluable help with other laboratory chores; to Samantha A. Seixas for her invaluable help in the laboratory, extracting the cirri for observation with the DIC microscope; to Cassandra de M. Monteiro and Jorge Bernardes for their help with collection of the hemipteran from Lago Tarumã; to Josiane B. Bandinelli and Peter Kleina for the collection of some hemipterans from Eldorado do Sul; and to Márcia Vignoli-Silva for the kindness of inking the drawings. 


\section{REFERENCES}

CANnON, L.R.G. 1993. New temnocephalans (Platyhelminthes): ectosymbionts of freshwater crabs and shrimps. Memoirs of the Queensland Museum, South Brisbane, 33: 17-40.

Cannon, L.R.G. \& K.B. Sewell. 1995. Craspedellinae Baer, 1931 (Platyhelminthes: Temnocephalida) ectosymbionts from the branchial chamber of Australian crayfish (Crustacea: Parastacidae). Memoirs of the Queensland Museum, South Brisbane, 38: 397-418.

Dallwitz, M.J. \& T.A. Paine. 1986. User's guide to the Delta system: a general system for processing taxonomic descriptions. CSIRO, Division of Entomology, Report 13, 106p.

Damborenea, M.C. \& L.R.G. Cannon. 2001. On neotropical Temnocephala (Platyhelminthes). Journal of Natural History, London, 35: 1103-1118.

Humason, G. 1972. Animal Tissue Techniques. San Francisco, W.H. Freeman, $3^{\text {rd }}$ ed., XV+641p.

Received in 01.VII.2004; accepted in 19.I.2005.
Joffe, B.I.; I.V. Solovei \& L.R.G. CANnON. 1995. The structure of the epidermis in Didymorchis (Temnocephalida: Platyhelminthes). Australian Journal of Zoology, Victoria, 43: 631-641.

Moretto, H.J.A. 1978. Presencia de Temnocephala (Temnocephalida, Platyhelmintes) em hemípteros acuáticos. Ciencia e Investigación, Buenos Aires, 34: 95-99.

Nieser, N. \& A.L. De Melo. 1997. Os heterópteros aquáticos de Minas Gerais. Belo Horizonte, UFMG, 180p.

RomeIs, B. 1968. Taschenbuch der microskopischen Technik. 16. Munchen, Aufl. Oldenbourg. XIV+695p.

Sewell, K.B. \& L.R.G. Cannon. 1998. New temnocephalans from the branchial chamber of Australian Euastacus and Cherax crayfish hosts. Proceedings of the Linnaean Society, New South Wales, 119: 21-36.

Vianna, G.J.C. \& A.L. DE Melo. 2002. Aquatic Heteroptera as host of Temnocephala Blanchard (Platyhelminthes: Temnocephalidae) in Minas Gerais, Brazil. Lundiana, Belo Horizonte, 3: 151-153.

Revista Brasileira de Zoologia 22 (1): 107-118, março 2005 